\title{
Pemanfaatan Perpustakaan Sekolah Sebagai Sumber Belajar Siswa Sekolah Dasar Negeri 111/IX Muhajirin
}

\author{
Wara Supatni ${ }^{1}$ \\ ${ }^{1}$ Guru SDN 111/IX Desa Muahjirin Kab. Muaro Jambi, Indonesia \\ Correspondance email: Edyisman01@gmail.com
}

\begin{abstract}
Abstrak: Masalah yang dikaji dalam penelitian ini adalah kurang maksimalnya pemanfaatan perpustakaan sekolah sebagai sumber belajar. Fokus Masalah: bagaimanakah pemanfaatan perpustakaan sekolah sebagai sumber belajar siswa SDN 111/IX Desa Muhajirin. Tujuan penelitian ini untuk mendeskripsikan pemanfaatan perpustakaan sekolah sebagai sumber belajar siswa SDN 111/IX Desa Muhajirin. Pendekatan yang digunakan pada penelitian ini adalah kualitatif. Jenis penelitian ini adalah penelitian deskriptif. Penelitian ini dilaksanakan dari kelas I-VI SDN 111/IX Desa Muhajirin pada bulan Februari-April 2019. Subjek dalam penelitian ini adalah siswa kelas I-VI SDN 111/IX Desa Muhajirin, yang berjumlah 30 orang yang terdiri dari 16 laki-laki dan 14 perempuan, wali kelas, pustakawan, serta kepala sekolah. Pengumpulan data dalam penelitian ini menggunakan lembar observasi, wawancara, dan dokumentasi. Teknik analisis datanya menggunakan reduksi data, penyajian data, dan mengambil kesimpulan. Hasil penelitian dapat diketahui bahwa pemanfaatan perpustakaan sekolah sebagai sumber belajar belum optimal. Jadi, dapat disimpulkan bahwa pemanfaatan perpustakaan sekolah sebagai sumber belajar siswa SDN 111/IX Desa Muhajirin belum berjalan secara optimal.
\end{abstract}

Kata Kunci: Perpustakaan Sekolah, Sumber Belajar

Abstract. The problem examined in this study is the lack of maximum utilization of school libraries as learning resources. Focus of the problem: how to use the school library as a learning resource for students of SDN 111 / IX Muhajirin Village. The purpose of this study is to describe the use of school libraries as learning resources for students of SDN 111 / IX Muhajirin Village. The approach used in this research is qualitative. This type of research is descriptive research. This research was conducted from class I-VI SDN 111 / IX Muhajirin Village in February-April 2019. The subjects in this study were students of class I-VI SDN 111 / IX Desa Muhajirin, totaling 30 people consisting of 16 males and 14 women, homeroom teacher, librarian, and principal. Collecting data in this study using observation sheets, interviews, and documentation. The data analysis technique uses data reduction, data presentation, and drawing conclusions. The results showed that the use of the school library as a learning resource was not optimal. So, it can be concluded that the use of school libraries as a learning resource for students of SDN 111 / IX Muhajirin Village has not run optimally.

Keywords: School Libraries, Learning Resources

\section{PENDAHULUAN}

Sekolah merupakan lembaga atau bangunan yang digunakan untuk kegiatan belajar mengajar serta menjadi tempat memberi dan menerima pelajaran sesuai dengan tingkatannya (sekolah dasar, sekolah lanjutan, dan sekolah tinggi). Untuk menjadi sekolah, ada sarana dan prasarana yang harus dipenuhi, seperti ruang belajar, perpustakaan, kantor, dan lainnya. Selain itu yang menjadi faktor pendukung dari sebuah sekolah yaitu sumber belajar.

Menurut Sumiati dan Asra (2011), menyatakan "sumber belajar adalah bahan-bahan apa saja yang dapat dimanfaatkan untuk membantu guru maupun siswa dalam upaya mencapai suatu tujuan”. Segala sesuatu yang dimaksudkan adalah yang diperlukan dalam pembelajaran. Sumber belajar dapat dikelompokkan atas dasar berbagai sudut pandang. Dilihat dari cara memperoleh informasi, sumber belajar dapat dibagi menjadi jenis visual, audio, dan audiovisual. Disamping itu, Sitepu (2014) menyatakan bahwa "dilihat dari tujuan pembuatan sumber belajar dapat dibagi ke dalam kelompok sumber belajar yang sengaja dirancang dan dibuat/diproduksi khusus untuk keperluan belajar atau membelajarkan". Contohnya sumber belajar kelompok pertama ialah buku teks pelajaran, modul, laboratorium/tempat praktik, video pembelajaran, dan perpustakaan. Disamping itu. ada juga kelompok sumber belajar yang bukan dirancang, dibuat/diproduksi khusus untuk keperluan belajar atau membelajarkan.

Jenis sumber belajar yang menjadi pokok perhatian adalah perpustakaan, yang terdiri dari beberapa jenis yang tersebar di masyarakat, misalnya, perpustakaan sekolah, perpustakaan perguruan tinggi, perpustakaan khusus, 
dan perpustakaan umum. Jenis perpustakaan tersebut kalau dilihat dari fungsinya adalah sebagai pusat pelayanan masyarakat. Namun apabila diamati lebih lanjut, maka jenis perpustakaan tersebut bisa terdiri dari berbagai macam perpustakaan lagi yang secara spesifik berfungsi langsung terhadap lembaga yang menaunginya. Penyelenggaraan perpustakaan sekolah mengacu kepada Undang-Undang Republik Indonesia Nomor 20 Tahun 2003, tentang Sistem Pendidikan Nasional (Sisdiknas) pasal 45 ayat (1) bahwa "setiap pendidikan formal dan nonformal menyediakan sarana dan prasarana yang memenuhi keperluan pendidikan". Undang-Undang Nomor 43 Tahun 2007 tentang perpustakaan yaitu: Bahwa dalam rangka Meningkatkan kecerdasan kehidupan bangsa, perlu ditumbuhkan budaya gemar membaca melalui pengembangan dan pendayagunaan perpustakaan sebagai sumber informasi yang berupa karya tulis, karya cetak, dan/atau karya rekam.

Perpustakaan sekolah berada di Sekolah Dasar (SD), Sekolah Lanjutan Atas Pertama (SLTP), dan Sekolah Menengah Umum/Kejuruan (SMU/SMK). Demikian pula untuk jenis perpustakaan perguruan tinggi dan perpustakaan khusus. Diadakannya perpustakaan sekolah adalah untuk tujuan memenuhi kebutuhan informasi bagi masyarakat di lingkungan sekolah yang bersangkutan, khususnya para guru dan siswa. Perpustakaan berperan sebagai media dan sarana untuk menunjang kegiatan proses belajar mengajar (PBM) di tingkat sekolah. Perpustakaan juga berperan sebagai sumber belajar yang efektif serta memiliki manfaat yang cukup besar bagi setiap pembacanya. Keadaan dunia yang semakin mengglobal secara tidak langsung mengharuskan dan mempertajam pengamatan terhadap informasi-informasi yang beredar. Selain itu, keadaaan ini juga telah menuntut agar lebih memperbaiki kualitas diri. Salah satu kunci untuk mencapai beberapa poin tersebut adalah dengan terus menerus menggali banyak informasi. Pemanfaatan perpustakaan sebagai sumber belajar siswa dapat memperoleh banyak informasi baik itu informasi masa lampau maupun informasi masa kini.

Pemanfaatan perpustakaan sekolah sebagai sumber belajar merupakan sarana prasarana yang diharapkan dapat menunjang proses belajar mengajar di sekolah sehingga terwujudnya kualitas pendidikan Indonesia yang berperan penting dalam mencerdaskan kehidupan bangsa. Keberadaan perpustakaan sekolah adalah untuk memenuhi kebutuhan informasi bagi masyarakat lingkungan sekolah yang bersangkutan. Menurut Lasa (Novriliam dan Yunaldi, 2012) menyatakan bahwa "perpustakaan sekolah merupakan unit kerja yang menghimpun, mengolah, dan, menyajikan kekayaan intelektual untuk kepentingan pendidikan, penelitian, pelestarian informasi, dan rekreasi untuk mencerdaskan kehidupan bangsa".

\section{LANDASAN TEORI}

Menurut Novriliam dan Yunaldi (2012), penyelenggaraan perpustakaan yang baik dan benar meliputi koleksi perpustakaan, pengolahan koleksi dan pustaka, pelayanan perpustakaan, sarana dan prasarana perpustakaan. Namun pada kenyataannya, di beberapa sekolah yang telah diamati oleh peneliti yaitu pada saat Magang dan Program Kerja Lapangan (PPL) masih banyak juga sekolah yang kurang memperhatikan penyelenggaraan perpustakaan sekolah, sehingga warga sekolah khususnya siswa kurang menyadari keberadaan perpustakaan sekolah untuk dimanfaatkan sebagai pusat sumber belajar mengajar. Begitupula dengan kenyataan yang terjadi di SDN 111/IX Desa Muhajirin dari hasil pengamatan pada tanggal 15 Januari 2019 dan berdiskusi dengan siswa, guru, dan pustakawan bahwa siswa cenderung melihat buku tanpa membaca kemudian keluar dari perpustakaan, bahkan adapula beberapa siswa yang hanya senang untuk bermain pada saat waktu luangnya dibandingkan memanfaatkan perpustakaan untuk belajar. Senada dengan Anshar (2014), menyatakan pada saat jam istirahat, siswa lebih cenderung menghabiskan waktunya di tempat lain, bukan memanfaatkan waktu istirahat untuk membaca di perpustakaan.

Keterbatasan buku yang ada diperpustakaan mengakibatkan siswa jenuh dalam membaca, karena beberapa buku yang ada diperpustakaan hanya buku-buku lama yang sudah terlihat kusam, dan koleksi buku yang ada tidak ditambah sesuai dengan perkembangan informasi. Hal ini senada dengan Anshar (2014), menyatakan bahwa bukubuku yang ada diperpustakaan harus diperbaharui, agar pengunjung perpustakaan tidak merasa jenuh dengan berbagai bacaan yang ada, jangan hanya buku-buku yang lama yang menghiasi rak-rak buku, koleksi bacaan yang lain juga perlu diperhatikan seperti bacaan yang menyegarkan yang bersifat mendidik, ataupun buku-buku yang berkenaan dengan kesenian, agar mereka mempunyai jiwa seni dapat dikembangkan, dengan begitu, kreativitas, pola pikir serta imajinasi para siswa terus berkembang.

Berbagai upaya yang dilakukan oleh semua pihak sekolah khususnya guru dan pustakawan untuk meningkatkan pemanfaatan perpustakaan sebagai sumber belajar, misalnya ketika wali kelas tidak berada di dalam kelas maka pustakawan memanggil siswa dari kelas tersebut untuk masuk kedalam perpustakaan agar semua siswa tersebut tetap dapat belajar. Selain itu, guru mendorong semua siswa agar rajin membaca di perpustakaan sekaligus menekankan bahwa membaca buku itu sangat penting untuk menambah ilmu pengetahuan. Akan tetapi kebanyakan siswa lebih memilih untuk bermain di waktu luangnya ataupun hanya sekedar melihat-lihat buku yang ada di perpustakaan. Selain itu ada pula siswa yang rajin membaca di perpustakaan karena memang memiliki kegemaran dalam hal membaca. 


\section{METODE PENELITIAN}

Pada Penelitian ini menggunakan pendekatan kualitatif. Pengambilan sampel sumber data pada penelitian kualitatif dilakukan secara purposive sampling dan snowball sampling. Pada penelitian ini menggunakan teknik purposive sampling yaitu teknik pengambilan sampel sumber data dengan pertimbangan tertentu, dimana sampel yang ditentukan adalah orang yang dianggap paling tahu tentang apa yang kita harapkan. Peneliti menarik sampel 5 orang dari setiap tingkatan kelas dari jumlah 134 populasi/siswa yang ada di SDN 111/IX Desa Muhajirin Selain siswa yang dijadikan sampel sumber data yaitu kepala sekolah, wali kelas, dan pustakawan.

Teknik pengumpulan datanya dengan triangulasi. Sugiono (2015) menyatakan "teknik pengumpulan data dapat dilakukan dengan observasi (pengamatan), interview (wawancara), kuesioner (angket), dokumentasi dan gabungan keempatnya". Pada penelitian ini peneliti menggunakan teknik pengumpulan data dengan menggunakan gabungan dari observasi, wawancara, dan dokumentasi. Penelitian ini merupakan jenis penelitian deskriptif. Jenis penelitian deskriptif adalah data yang dikumpulkan adalah berupa kata-kata, gambar, dan bukan angka. Penelitian ini untuk mengumpulkan informasi suatu gejala yang ada, yaitu gejala menurut apa adanya pada saat penelitian dilakukan dengan menggambarkan apa adanya tentang suatu variabel.

Sumber data adalah segala sesuatu yang dapat memberikan informasi terkait dengan penelitian yang dilakukan. Untuk itu, agar peneliti bisa mengumpulkan data yang validitas dan realibilitas dapat dipertanggungjawabkan terkait dengan pemanfaatan perpustakaan sekolah sebagai sumber belajar siswa SDN 111/IX Desa Muhajirin, maka sumber data tersebut yaitu kepala sekolah, wali kelas, pustakawan, dan siswa SDN 111/IX Desa Muhajirin.

Penelitian kualitatif mengumpulkan data

dengan triangulasi (gabungan) yaitu pengumpulan data sebagai berikut ini :

\section{Observasi}

Observasi merupakan teknik pengumpulan data yang di lakukan dengan cara mengamati langsung apa yang diteliti, yaitu mengamati langsung pemanfaatan perpustakaan sekolah sebagai sumber belajar siswa SDN 111/IX Desa Muhajirin. Pada penelitian ini, peneliti menggunakan pengamatan participant observer dimana peneliti berpartisipasi aktif dalam kegiatan yang diamati. Pada penelitian ini peneliti melakukan penelitian secara terangterangan artinya informan mengetahui peneliti sedang melakukan penelitian.

2. Wawancara

Wawancara merupakan salah satu teknik yang dapat dalam pengumpulan data. Pada penelitian ini peneliti menggunakan wawancara terstruktur. Dimana wawancara terstruktur adalah suatu bentuk wawancara di mana pewawancara dalam hal ini peneliti menyusun secara terperinci dan sistematis rencana atau pedoman pertanyaan menurut pola tertentu dengan menggunakan format yang baku secara tertulis. Teknik wawancara ini dilakukan kepada kepala sekolah, wali kelas, pustakawan, dan siswa SDN 111/IX Desa Muhajirin.

3. Dokumentasi

Dokumen dalam penelitian ini berkaitan dengan pemanfaatan perpustakaan sekolah sebagai sumber belajar siswa SDN 111/IX Desa Muhajirin misalnya saja buku pengunjung, daftar peminjaman buku, dan lain sebagainya. Data yang diperoleh sepanjang proses penelitian ini dianalisis sejak awal penelitian.

Adapun langkah-langkah analisis data yang biasa digunakan dalam penelitian kualitatif yaitu, Model Miles dan Huberman (Sugiono, 2015) yang membagi atas 3 (tiga) macam analisis data selama lapangan yaitu:

1. Reduksi Data

Reduksi data menunjuk kepada proses pemilihan, pemokusan, penyederhanaan,pemisahan, dan pentransformasian data "mentah" yang terlihat dalam catatan tertulis lapangan. Data yang diperoleh di lapangan ditulis atau diketik dalam bentuk uraian terperinci, selain dapat memberi gambaran yang tebih tajam tentang hasil pengamatan, juga mempermudah peneliti untuk mencari kembali data yang diperoleh bila diperlukan.

2. Penyajian Data

Data yang diperoleh disajikan dalam bentuk uraian singkat, dan sejenisnya agar peneliti dapat melihat gambaran keseluruhan dan dapat menguasainya. Penyajian data dalam konteks ini adalah kumpulan informasi yang telah tersusun yang membolehkan penarikan kesimpulan dan pengambilan tindakan.

3. Kesimpulan dan Verifikasi

Data yang diperoleh selama proses penelitian setelah dilakukannya reduksi data dan penyajian data ditarik kesimpulan dan diverifikasi agar memperoleh suatu teori yang memiliki makna data yang dikumpulkan

Penarikan kesimpulan berdasarkan pengolahan data dan diuraikan sehingga menghasilkan kesimpulan yang sesuai tentang pemanfaatan perpustakaan sekolah sebagai sumber belajar SDN 111/IX Desa Muhajirin. Pengecekan keabsahan temuan dilakukan untuk meminimalisir terjadinya kesalahan data yang dikumpulkan selama melakukan penelitian dengan cara melakukan pengecekan kembali data yang sudah ada dan terkumpul dari berbagai sumber data dengan berbagai macam teknik pengumpulan data sebelumnya. Kegiatan ini meliputi beberapa langkah yaitu: 


\section{Ketekunan Pengamatan}

Peneliti melakukan pengamatan terhadap hal-hal yang berkaitan dengan apa yang ingin diteliti. Ketekunan pengamatan bermaksud menemukan unsur-unsur dalam situasi yang relevan dengan persoalan atau yang sedang dicari dan kemudian memusatkan diri pada hal-hal tersebut. Untuk itu peneliti melakukan pengamatan langsung tentang pemanfaatan perpustakaan sekolah. Hal ini bertujuan untuk mengetahui keadaan yang sebenarnya yang terjadi di lapangan dan juga data yang didapatkan menjadi lebih rinci.

2. Triangulasi

Pengumpulan data yang digunakan oleh calon peneliti yaitu triangulasi (observasi, wawancara, dan dokumentasi), maka sebenarnya peneliti mengumpulkan data sekaligus menguji kredibilitas (derajat kepercayaan) data. Triangulasi berarti cara terbaik untuk menghilangkan perbedaan-perbedaan konstruksi kenyataan yang ada sewaktu mengumpulkan data tentang berbagai kejadian dan hubungan dari berbagai pandangan. Dalam hal ini peneliti melakukan pengamatan di SDN 111/IX Desa Muhajirin, dengan mewawancarai kepala sekolah, guru, pustakawan, dan siswa.

Pada proses pelaksanaan penelitian ini, tahap-tahap penelitian ini meliputi beberapa tahapan, diantaranya sebagai berikut:

1. Penelitian pendahuluan, yaitu peneliti melakukan pengamatan mengenai pemanfaatan perpustakaan sekolah sebagai sumber belajar di SDN 111/IX Desa Muhajirin. Peneliti melakukan pengamatan beberapa kali karena penelitian kualitatif memerlukan data yang akurat dan dapat dipercaya.

2. Pengumpulan data yaitu peneliti mengumpulkan informasi atau pengamatan yang didapatkan sehingga menghasilkan data pada pemanfaatan perpustakaan sekolah sebagai sumber belajar.

3. Penulisan laporan yaitu peneliti menulis laporan sesuai hasil data dan informasi yang didapatkan peneliti dari pemanfaatan perpustakaan sekolah sebagai sumber belajar.

\section{HASIL DAN PEMBAHASAN}

Penelitian ini dilaksanakan di SDN 111/IX Desa Muhajirin Kecamatan Jambi Luar Kota Kabupaten Muaro Jambi tentang pemanfaatan perpustakaan sekolah sebagai sumber belajar. Yang terlibat dalam penelitian ini selain dari peneliti sendiri adalah siswa, wali kelas, pustakawan, kepala sekolah, dan sumber belajar khususnya perpustakaan. Penelitian ini dilaksanakan mulai tanggal 19-31 Maret 2019. Data hasil penelitian diperoleh dari siswa SDN 111/IX Desa Muhajirin yang terpilih sebagai informan sebanyak 30 (tiga puluh) siswa, wali kelas, pustakawan, dan kepala sekolah. Hal yang menjadi pembahasan dalam hasil penelitian ini adalah bagaimana pemanfaatan perpustakaan sekolah sebagai sumber belajar di SDN 111/IX Desa Muhajirin dengan menggunakan teknik observasi, teknik wawancara, dan teknik dokumentasi.

\section{Perpustakaan SDN 111/IX Desa Muhajirin}

Ruangan perpustakaan SDN 111/IX Desa Muhajirin cukup bersih dan memiliki perlengkapan berupa 12 buah meja baca yang disusun berbentuk "U" tanpa disertai dengan kursi baca. Lantai perpustakaan bertegel warna putih dan diberikan karpet berwarna hijau tua sebagai alas bagi siswa untuk membaca. Meja diletakkan tepat ditengah ruangan sehingga tidak mengganggu aktifitas pengunjung selama membaca buku di perpustakaan begitupula dengan pengunjung yang hendak mengambil buku di rak buku. Terdapat 5 rak buku dimana 3 rak buku disusun berderet di sisi timur meja baca dan 2 rak lainnya masing-masing diletakkan di sudut perpustakaan. Selain itu terdapat pula 3 buah meja dan 3 buah kursi untuk pustakawan dan guru yang digunakaan pada saat proses pembelajaran yang dilaksanakan di perpustakaan. Terdapat pajangan-pajangan bertuliskan motivasi-motivasi untuk selalu rajin membaca dan foto Presiden dan Wakil Presiden.

Perlengkapan perpustakaan SDN 111/IX Desa Muhajirin masih membutuhkan penambahan perlengkapan dari segi pajangan, misalnya saja belum terdapat lambang negara RI yaitu foto Burung Garuda, belum terdapat kipas angin ataupun pendingin udara serta belum tersedianya komputer dan wifi yang dapat mendukung beragamnya referensi ataupun informasi yang dibutuhkan oleh siswa. Selain beberapa perlengkapan yang ada di perpustakaan juga terdapat tata tertib perpustakaan yang harus ditaati oleh semua pengunjung perpustakaan. Adapun isi dari tata tertib perpustakaan adalah sebagai berikut:

a. Menunjukkan kartu tanda anggota perpustakaan jika menggunakan fasilitas perpustakaan.

b. Meninggalkan tas, map, jaket, jas, dan semua barang tidak diperlukan di loker yang telah tersedia

c. Pemustaka harus mengisi buku tamu yang telah disediakan

d. Pemustaka wajib menjaga kebersihan, ketenangan, serta tidak diperkenankan merokok, makan dan minum di dalam perpustakaan

e. Kunci loker dikembalikan setelah selesai berkunjung di perpustakaan

f. Kartu anggota perpustakaan tidak dibenarkan untuk meminjamkan kepada orang lain. 
g. Buku perpustakaan yang sedang di pinjam anggota atas nama dirinya tidak dibenarkan untuk dipinjamkan kepada orang lain.

h. Keterlambatan pengembalian buku dikenakan denda yang besarnya telah ditentukan

i. Pemustaka yang tidak atau sengaja melanggar peraturan dan tata tertib perpustakaan dapat dikenakan sanksi

Berdasarkan wawancara peneliti dengan informan beberapa aturan sudah diketahui oleh pengunjung diantaranya 12 orang informan menyatakan tidak boleh ribut, 3 orang informan yang menyatakan harus rajin membaca, 4 orang informan tidak boleh bertengkar, 2 orang informan menyatakan tidak boleh menghambur buku, 2 orang informan menyatakan tidak boleh merobek buku, 1 orang menyatakan tidak boleh mencuri, dan 4 orang informan yang menyatakan tidak tahu. Tata tertib yang telah disusun ini belum sepenuhnya dipatuhi oleh semua pengunjung.

Aturan yang paling sering dilanggar oleh para pengunjung perpustakaan yaitu, aturan pada bagian a) setiap pengunjung tidak pernah menunjukkan kartu tanda anggotanya ketika berkunjung ke perpustakaan. Bagian b) karena belum tersedianya loker maka setiap pengunjung tidak dapat menyimpan tas, jaket maupun semua barang-barang dari setiap pengunjung sehingga barang-barang pengunjung tampak berserakan disekitar meja baca pada saat pengunjung membaca di perpustakaan. Bagian c) pengunjung perpustakaan jarang mengisi buku tamu yang telah disediakan, pengunjung mengisi buku tamu apabila diingatkan oleh pustakawan. Bagian d) siswa dilarang membawa makanan dan minuman ke perpustakaan dan menjaga ketenangan selama berada di perpustakaan akan tetapi masih terdapat pengunjung yang melanggar.

Dari segi penggunaan kartu peminjaman buku, selama peneliti melakukan penelitian di SDN 111/IX Desa Muhajirin siswa belum pernah meminjam buku di perpustakaan. Kemudian peneliti mengecek akan tetapi dicatatan buku peminjaman perpustakaan sebelum peneliti meneliti di SDN 111/IX Desa Muhajirin sudah terdapat siswa yang meminjam buku di perpustakaan meskipun jumlah siswa yang meminjam buku masih relatif kurang. Hasil wawancara peneliti dengan informan, dari 30 siswa yang dipilih sebagai informan 12 orang menyatakan tidak pernah meminjam buku, 14 orang informan menyatakan sering meminjam buku, dan 4 orang menyatakan jarang meminjam buku.

\section{Penyelenggaraan Perpustakaan SDN 111/IX Desa Muhajirin}

Penyelenggaraan perpustakaan yang baik dan benar meliputi koleksi perpustakaan, pelayanan perpustakaan, sarana dan prasarana perpustakaan, pengolahan koleksi dan pustaka, pelayanan perpustakaan, sarana dan prasarana perpustakaan. Dengan adanya penyelenggaraan perpustakaan yang benar, maka perpustakaan dapat dimanfaatkan secara optimal sebagai sumber belajar di sekolah. Penyelenggaraan perpustakaan di SDN 111/IX Desa Muhajirin meliputi beberapa hal yaitu:

a. Koleksi Perpustakaan SD 111/IX Desa Muhajirin

Koleksi merupakan elemen yang penting dalam eksistensi sebuah perpustakaan. Pada saat ini perpustakaan SDN 111/IX Desa Muhajirin memiliki 787 koleksi yang tersedia dalam bentuk buku maupun non buku. Sebagai pusat sumber belajar perpustakaan sekolah ini memiliki 50 eksemplar bahan koleksi buku, yang terdiri dari macammacam buku yang dibutuhkan dalam proses belajar mengajar maupun buku-buku lainnya. Selain dari koleksi buku, perpustakaan sekolah ini juga memiliki bahan koleksi non buku yaitu alat peraga. Beberapa koleksi alat peraga yang terdapat di perpustakaan SDN 111/IX Desa Muhajirin yaitu alat peraga untuk mata pelajaran Bahasa Indonesia, Bahasa Inggris, Matematika, Ilmu Pengetahuan Alam (IPA), dan Ilmu Pengetahuan Sosial (IPS). Semua koleksi yang ada di perpustakaan SDN 111/IX Desa Muhajirin diharapkan dapat dimanfaatkan oleh siswa maupun guru dalam mendapatkan informasi dan ilmu pengetahuan. Semua alat peraga disimpan didalam kardus dan diletakkan di rak buku paling atas. Semua koleksi perpustakaan SDN 111/IX Desa Muhajirin dapat dirincikan seperti tabel dibawah yang di peroleh dari dokumentasi buku inventaris perpustakaan SDN 111/IX Desa Muhajirin tersebut sebagai berikut:

Tabel 1

\begin{tabular}{lc} 
Jumlah Koleksi Perpustakaan SDN & $111 /$ IX Desa Muhajirin \\
\hline Koleksi & Jumlah \\
\hline Buku Fiksi & 706 \\
Buku Nonfiksi & 44 \\
Alat Peraga & 11 \\
Non Buku & 26 \\
Total & $\mathbf{7 8 7}$ \\
\hline
\end{tabular}

b. Pengadaan Koleksi

Pengadaan koleksi adalah upaya untuk menghimpun bahan pustaka untuk dijadikan koleksi perpustakaan. Pengadaan koleksi harus dilakukan pada setiap perpustakaan, begitu pula pada perpustakaan SDN 111/IX Desa 
Muhajirin. Penambahan koleksi perpustakaan di SDN 111/IX Desa Muhajirin dilakukan apabila sekolah mendapat bantuan dana dari pemerintah. Menurut pustakawan SDN 111/IX Desa Muhajirin pada saat diwawancarai untuk penambahan koleksi perpustakaan yang diperoleh dari dana Bantuan Operasional Sekolah (BOS), dana khusus alokasi untuk pemberdayaan perpustakaan, serta bantuan buku yang diberikan oleh dinas. Minimnya dana menyebabkan terbatasnya koleksi yang dapat dibeli oleh SDN 111/IX Desa Muhajirin. Keadaan rak buku masih belum terisi penuh dengan buku-buku perpustakaan. Hanya terdiri dari buku-buku pelajaran yang merupakan terbitan lama dan sudah terlihat kusam. Keadaan rak buku belum terisi penuh dengan buku, dan buku yang tersedia merupakan buku terbitan lama yang terlihat kusam dengan penataan buku yang kurang rapi.

Penataan buku yang kurang rapi dinyatakaan oleh siswa pada saat diwawancarai oleh peneliti yaitu dari 30 siswa yang dipilih sebagai informan, 18 orang informan yang menyatakan rapi, 6 orang informan menyatakan tidak rapi, 5 orang informan menyatakan kurang rapi, dan 1 orang menyatakan tidak tahu, jika dijumlahkan 11 orang yang menyatakan belum rapi. Ini juga dapat dilihat dari dokumentasi peneliti tentang kondisi buku yang disimpan di rak buku. Dampak dari hal tersebut adalah siswa kesulitan untuk mencari buku yang mereka minati.

Perpustakaan SDN 111/IX Desa Muhajirin juga belum terdapat buku cerita seperti buku dongeng maupun buku cerita lainnya yang dapat menarik minat baca siswa. Berdasarkan surve buku pelajaran di perpustakaan sudah tersedia meskipun masih buku lama dan hanya sedikit buku pelajaran baru, akan tetapi dari segi buku cerita ataupun buku-buku dongeng dan buku cerita lainnya belum tersedia, padahal buku cerita seperti itu akan lebih menarik minat siswa untuk membaca buku di perpustakaan karena sesuai dengan kondisi siswa.

\section{Kehadiran Pengunjung Perpustakaan}

Perpustakaan merupakan gudang informasi bagi setiap sekolah. Perpustakaan sekolah dikatakan berfungsi dengan baik apabila terdapat pengunjung yang memanfaatkannya sebagai sumber belajar. Kehadiran pengunjung perpustakaan atau yang lebih dikenal dengan istilah pemustaka di perpustakaan merupakan tolak ukur keberhasilan suatu perpustakaan. Semakin banyak jumlah pengunjung maka perpustakaan tersebut dikatakan berhasil. Berikut tingkat kunjungan warga sekolah di perpustakaan SDN 111/IX Desa Muhajirin:

a. Siswa

Pemanfaatan perpustakaan sekolah sebagai sumber belajar di SDN 111/IX Desa Muhajirin ini belum optimal. Hal ini dapat disimpulkan dari kondisi perpustakaan yang sepi pengunjung yang terlihat di dalam buku kunjungan perpustakaan. Berdasarkan hasil wawancara peneliti dengan siswa SDN 111/IX Desa Muhajirin, dari 30 siswa yang dipilih menjadi informan, 10 orang informan yang menyatakan berkunjung ke perpustakaan sebanyak tiga kali dalam seminggu, 8 orang informan menyatakan berkunjung ke perpustakaan sebanyak dua kali seminggu, 3 orang informan menyatakan berkunjung ke perpustakaan sebanyak empat kali seminggu, 2 orang informan menyatakan berkunjung ke perpustakaan sebanyak lima kali seminggu, 4 orang informan menyatakan berkunjung ke perpustakaan sebanyak satu kali seminggu, dan 3 orang informan menyatakan tidak pernah sama sekali berkunjung ke perpustakaan dalam seminggu. Informan SDN 111/IX Desa Muhajirin paling banyak menjawab berkunjung ke perpustakaan sebanyak tiga kali dalam seminggu.

Bapak/ibu guru SDN 111/IX Desa Muhajirin selalu menyampaikan kepada siswa bahwa di sekolah terdapat perpustakaan yang dapat digunakan untuk membaca atau mencari bahan pelajaran. Membaca merupakan langkah awal untuk mendapatkan ilmu, sehingga dengan membaca siswa akan memperoleh banyak ilmu yang sangat bermanfaat. Pustakawan telah menyusun jadwal masing-masing kelas untuk belajar di perpustakaan dengan harapan perpustakaan akan ramai pengunjung sekaligus melatih siswa untuk rajin membaca di perpustakaan. Untuk hari senin dijadwalkan untuk kelas II, selasa untuk kelas III, rabu untuk kelas I, kamis untuk V, jumat untuk kelas IV, dan sabtu untuk kelas VI. Jadwal kunjungan siswa ke perpustakaan belum dijalankan dengan baik oleh siswa SDN 111/IX Desa Muhajirin. Kondisi ini disebabkan oleh siswa yang lebih tertarik bermain di halaman sekolah serta lebih memilih beraktifitas di kelas baik itu membaca, menulis, maupun bermain.

Semua wali kelas menyatakan bahwa yang berkunjung ke perpustakaan SDN 111/IX Desa Muhajirin harus disertai dengan minat, dorongan, dan kemauan dari dalam diri. Karena tanpa adanya minat, siswa yang datang ke perpustakaan hanya akan datang untuk bermain ataupun ribut di perpustakaan. Semua wali kelas juga menyatakan bahwa zaman sekarang yang namanya anak-anak akan lebih suka bermain, ketika tidak dipaksa untuk belajar ataupun diberikan dorongan lebih untuk belajar maka hasilnya akan sama. Mereka akan lebih suka bermain, hanya siswa yang tergolong pandai yang rajin membaca buku di perpustakaan sebaliknya siswa yang kurang pandai lebih menyukai bermain.

Berdasarkan hasil observasi dan dokumentasi mengenai pemanfaatan perpustakaan sekolah di kalangan siswa, dari 134 siswa rata-rata kunjungan siswa di perpustakaan sebanyak 6 orang setiap harinya. Jumlah ini masih terhitung relatif, tergantung dari kemauan siswa untuk berkunjung ke perpustakaan dan permintaan dari masingmasing wali kelas untuk belajar di perpustakaan. Sehingga jika dirata-ratakan persentase kunjungan siswa yang datang di perpustakaan dalam seminggu adalah 26\%. Presentase ini masih tergolong rendah, bahkan frekuensi kunjungan tidak mencapai $50 \%$ dari jumlah siswa. 
Presentase kunjungan siswa di perpustakaan dipengaruhi oleh beberapa faktor yaitu kondisi perpustakaan kurang sejuk. Menurut siswa kelas V, yang sering membuatnya merasa malas untuk berkunjung ke perpustakaan yaitu kondisi perpustakaan terasa panas karena tidak terdapat kipas angin sehingga membuatnya merasa tidak nyaman dan betah membaca di perpustakaan. Selain itu, yang membuat siswa malas ke perpustakaan yaitu siswa tidak ingin berada di perpustakaan apabila tidak ditemani oleh temannya untuk membaca di perpustakaan. Siswa paling senang membaca jika bersama-sama ke perpustakaan, dengan bersama-sama siswa akan mendapat teman untuk bertukar cerita tentang apa yang mereka baca. Akan tetapi kebanyakan siswa lebih memilih untuk berada di kelas, di kantin, ataupun dihalaman sekolah baik untuk bermain maupun bercerita. Hal ini senada dengan apa yang dinyatakan oleh Rahmat Anugrah siswa kelas VI yang menyatakan tidak berminat ke perpustakaan apabila hanya sendiri tanpa ditemani oleh teman-teman baik hanya satu orang maupun beramai-ramai. Sedangkan menurut semua wali kelas buku yang ada di perpustakaan belum sepenuhnya memenuhi kebutuhan siswa, buku yang ada di perpustakaan masih perlu untuk ditambah misalnya buku cerita yang dapat menunjang minat dan ketertarikan siswa dalam membaca.

\section{b. Tenaga Pengajar}

Perpustakaan sekolah bukan hanya diperuntukkan untuk siswa akan tetapi perpustakaan dibuka bagi seluruh warga sekolah misalnya guru dan kepala sekolah. Jumlah guru di SDN 111/IX Desa Muhajirin sebanyak 11 orang yang terdiri dari 7 wali kelas, 2 guru olahraga, 1 pustakawan, dan 1 guru agama. Tingkat kehadiran guru diperpustakaan juga masih tergolong rendah. Guru lebih senang berada di kelas masing-masing saat jam istirahat baik itu duduk ataupun bermain handphone. Kegiatan yang dilakukan juga oleh guru pada saat jam istirahat yaitu duduk di kantin sekolah bersama dengan guru yang lainnya serta kepala sekolah. Mereka senang bercerita di kantin sekolah, bersendau gurau bersama-sama sambil membeli makanan ataupun minuman yang tersedia.

Selama melakukan penelitian di perpustakaan SDN 111/IX Desa Muhajirin guru yang berkunjung di perpustakaan datang untuk bercerita dengan pustakawan ataupun hanya datang melihat-lihat di perpustakaan. Tercatat di buku kunjungan guru dan pegawai perpustakaan sebelum peneliti melaksanakan penelitian di SDN 111/IX Desa Muhajirin setiap harinya hanya 1 (satu) orang guru yang berkunjung diperpustakaan. Sedangkan tingkat kunjungan kepala SDN 111/IX Desa Muhajirin terbilang jarang karena kepala sekolah sibuk dengan berbagai kegiatan di luar sekolah. Kehadiran kepala sekolah di perpustakaan hanya datang untuk memantau kegiatan-kegiatan yang berlangsung di perpustakaan. Berdasarkan tingkat kunjungan perpustakaan dikalangan guru SDN 111/IX Desa Muhajirin, dari 10 orang guru rata-rata 1 (satu) orang yang berkunjung setiap harinya di perpustakaan, jika dipresentasekan hanya $10 \%$ guru yang berkunjung setiap harinya di perpustakaan.

Perpustakaan sekolah sangat memberi manfaat besar bagi siswa maupun warga sekolah lainnya. Dengan banyak memanfaatkan perpustakaan siswa akan memperluas ilmu dan informasinya. Peran guru dan pustakawan berperan penting dalam pemanfaatan perpustakaan sekolah. Guru dan pustakawan harus menjadi teladan atau contoh bagi siswa dalam memanfaatkan perpustakaan. Ketika guru dan pustakawan memberikan contoh maka siswa akan terdorong dengan sendirinya untuk rajin berkunjung sekaligus membaca di perpustakaan. Guru harus selalu mengayomi siswanya agar dapat menjadi pribadi yang baik dan berkarakter dan bermanfaat untuk masa depannya kelak.

Kunjungan siswa di perpustakaan SDN 111/IX Desa Muhajirin masih memerlukan perhatian untuk segi pemanfaatannya sebagai sumber belajar baik dari wali kelas, pustakawan, maupun kepala sekolah. Pada saat informan diwawancarai oleh peneliti tentang seringnya memanfaatkan perpustakaan di waktu luangnya maka jawaban informan yaitu dari 30 siswa yang dipilih sebagai informan, 13 orang informan yang menyatakan tidak memanfaatkan perpustakaan diwaktu luangnya, 9 orang informan menyatakan memanfaatkan perpustakaan diwaktu luangnya, 4 orang informan menyatakan jarang memanfaatkan perpustakaan diwaktu luangnya, dan 4 orang informan menyatakan sering memanfaatkan perpustakaan diwaktu luangnya. Hal ini menunjukkan bahwa siswa cenderung belum memanfaatkan perpustakaan sesering mungkin karena jawaban negatif dari informan berjumlah 17 orang lebih mendominasi jawaban positif yang berjumlah 13 orang.

Koleksi buku fiksi dan nonfiksi juga belum memadai, harapan dari semua guru untuk pihak sekolah agar buku-buku yang ada di perpustakaan kiranya dilengkapi, misalnya buku-buku cerita agar dapat mendorong siswa untuk rajin masuk ke dalam perpustakaan. Begitupula dengan fasilitasnya, dari hasil wawancara 12 orang informan menyatakan di dalam perpustakaan terasa panas karena tidak terdapat kipas angin sehingga merasa kurang betah berada di perpustakaan untuk membaca buku. Pendekatan penelitian ini menggunakan penelitian kualitatif dan menggunakan jenis penelitian deskriptif. Hasil penelitiannya menunjukkan betapa pentingnya pemanfaatan perpustakaan sebagai sumber belajar khususnya di sekolah dasar untuk menunjang proses belajar mengajar. Agar dapat menunjang proses belajar mengajar, maka dalam pengadaan bahan pustaka hendaknya mempertimbangkan kurikulum sekolah, serta selera para pembaca yang dalam hal ini adalah siswa.

Perpustakaan sekolah dalam penyelenggaraannya bukan hanya untuk mengumpulkan dan menyimpan bahanbahan pustaka, tetapi melalui penyelenggaraan perpustakaan sekolah diharapkan dapat membantu siswa dan guru dalam menyelesaikan tugas-tugas dalam proses belajar mengajar. Pendekatan penelitian ini menggunakan penelitian 
kualitatif dan menggunakan jenis penelitian deskriptif. Hasil penelitiannya menunjukkan betapa pentingnya pemanfaatan perpustakaan sebagai sumber belajar khususnya di sekolah dasar untuk menunjang proses belajar mengajar. Agar dapat menunjang proses belajar mengajar, maka dalam pengadaan bahan pustaka hendaknya mempertimbangkan kurikulum sekolah, serta selera para pembaca yang dalam hal ini adalah siswa.

Siswa SDN 111/IX Desa Muhajirin ketika diwawancarai mengenai perpustakaan membantu mereka dalam mengerjakan tugas dari 30 siswa yang dipilih menjadi informan 10 orang menyatakan tidak membantu, 1 orang yang menyatakan tidak tahu, 12 orang menyatakan membantu, 5 orang menyatakan sering, dan 2 orang menyatakan terkadang. Berarti dari pendapat informan tersebut masih ada yang menyatakan belum membantu siswa dalam menyelesaikan tugas sehingga perpustakaan belum terselenggarakan dengan baik. Perpustakaan terlihat bermanfaat apabila benar-benar dapat memperlancar pencapaian tujuan proses belajar mengajar di sekolah. Manfaat tersebut tidak hanya berupa tingginya prestasi siswa, tetapi lebih jauh lagi, antara lain adalah siswa mampu mencari, menemukan, menyaring, dan menilai informasi, siswa akan terbiasa belajar mandiri, siswa akan terlatih kearah tanggung jawab, siswa selalu mengikuti perkembangan ilmu pengetahuan dan teknologi, dan sebagainya.

Menurut Bafadal (2014), menyatakan bahwa "perpustakaan sekolah merupakan salah satu sarana pendidikan dalam mengembangkan pengetahuan, keterampilan, dan sikap murid". Sekolah harus lebih memperhatikan kondisi perpustakaan sekolah ini dikarenakan perpustakaan sekolah memberikan pengaruh yang cukup tinggi. Penyelenggaraan perpustakaan memerlukan ruang khusus beserta sarananya. Semakin lengkap perlengkapannya, semakin baik pula penyelenggaraan perpustakaan sekolah khususnya dalam upaya mencari bahan-bahan sebagai materi tambahan di kelas dan sebagai suatu usaha meningkatkan pengalaman, kebiasaan belajar siswa ataupun meningkatkan kemampuan perpustakaan yang diselenggarakan oleh sekolah menjadi sumber belajar yang optimal bagi siswa maupun semua warga sekolah.

Intensitas kunjungan siswa ke perpustakaan tergolong masih rendah, hal ini dapat diukur dari daftar hadir kunjungan siswa. Dibuktikan juga dari jawaban informan pada butir pertanyaan 1. Dari 30 siswa yang diwawancarai paling banyak menjawab berkunjung ke perpustakaan sebanyak (tiga) kali dalam seminggu dan rata-rata 6 orang yang berkunjung setiap harinya, jika di presentasekan hanya 26\% setiap minggunya. Presentase ini diperoleh dari rata-rata kunjungan siswa dibagi dengan jumlah keseluruhan siswa yaitu 134 siswa. Sedangkan tingkat kunjungan guru di perpustakaan sesuai dengan buku kunjungan guru yang berkunjung hanya 1 (satu) orang setiap harinya jika di presentasikan hanya $60 \%$ setiap minggunya yang diperoleh dari rata-rata kunjungan guru dibagi dengan jumlah guru sebanyak 10 orang dengan presentasi kunjungan yang masih terhitung relatif. Jumlah keseluruhan warga sekolah SDN 111/IX Desa Muhajirin yaitu 144 orang dengan rata-rata kunjungan ke perpustakaan sekolah paling banyak 42 orang setiap bulannya.

\section{SIMPULAN}

Berdasarkan hasil penelitian dan pembahasan, kesimpulan penelitian ini adalah pemanfaatan perpustakaan sekolah sebagai sumber belajar siswa SDN 111/IX Desa Muhajirin belum berjalan secara optimal, ini dikarenakan penyelenggaraan perpustakaan yang masih tergolong baru dan masih membutuhkan banyak perbaikan baik dari minat pengunjung maupun dari segi penambahan koleksi dan segi pelayanan.

\section{DAFTAR PUSTAKA}

Ahmadi, Rulam. 2014. Metodologi Penelitian Kualitatif. Yogyakarta: Ar-Ruzz Media.

Anshar, Bimba. 2016. Artikel Ciri Perpustakaan Sekolah Yang Ideal, (Online),

Febrizki, Suhartama. 2012. Manfaat Perpustakaan Bagi Peserta didik,

Indrawan, Rully \& Poppy Yaniawati. 2014. Metodologi Penelitian Kuantitatif, Kualitatif, dan Campuran Untuk Manajemen, Pembangunan, Dan Pendidikan. Bandung : Refika Aditama.

Moleong, Lexy J. 2015. Metodologi Penelitian Kualitatif. Bandung: Remaja Rosdakarya.

Musfah, Jejen. 2011. Peningkatan Kompetensi Guru Melalui Pelatihan dan Sumber Belajar Teori dan

Praktik. Jakarta :Kencana Prenada Media Group.

Novriliam, Rio \& Yunaldi. 2012. Pemanfaatan Perpustakaan Sekolah sebagai Sumber Pusat Sumber Belajar di Sekolah Dasar Negeri 23 Painan Utara. Padang: Universitas Negeri Padang.

Sari, Fitria Novi. 2014. Pengertian, Fungsi, Jenis-Jenis, dan Pemanfaatan Sumber Belajar, (Online),

Satori, Djam'an \& Aan Komariah. 2010. Metodologi Penelitian Kualitatif. Bandung: Penerbit Alfabeta.

Sitepu. 2014. Pengembangan Sumber Belajar. Jakarta: Rajagrafindo Persada.

Sugiono. 2015. Metode Penelitian Pendidikan Pendekatan Kuantitatif, Kualitatif, dan R\&D. Bandung: Penerbit Alfabeta. 
Sumiati \& Asra. 2011. Metode Pembelajaran. Bandung: Penerbit CV Wacana Prima.

Suwarno, Wiji. 2010. Pengetahuan Dasar Kepustakaan Sisi Penting Perpustakaan dan Pustakawan. Bogor: Penerbit Ghalia Indonesia.

Yusuf, Pawit \& Yaya Suhendar. 2013. Pedoman Penyelenggaraan Prenada Media Group.

Perpustakaan Sekolah. Jakarta: Kencana 